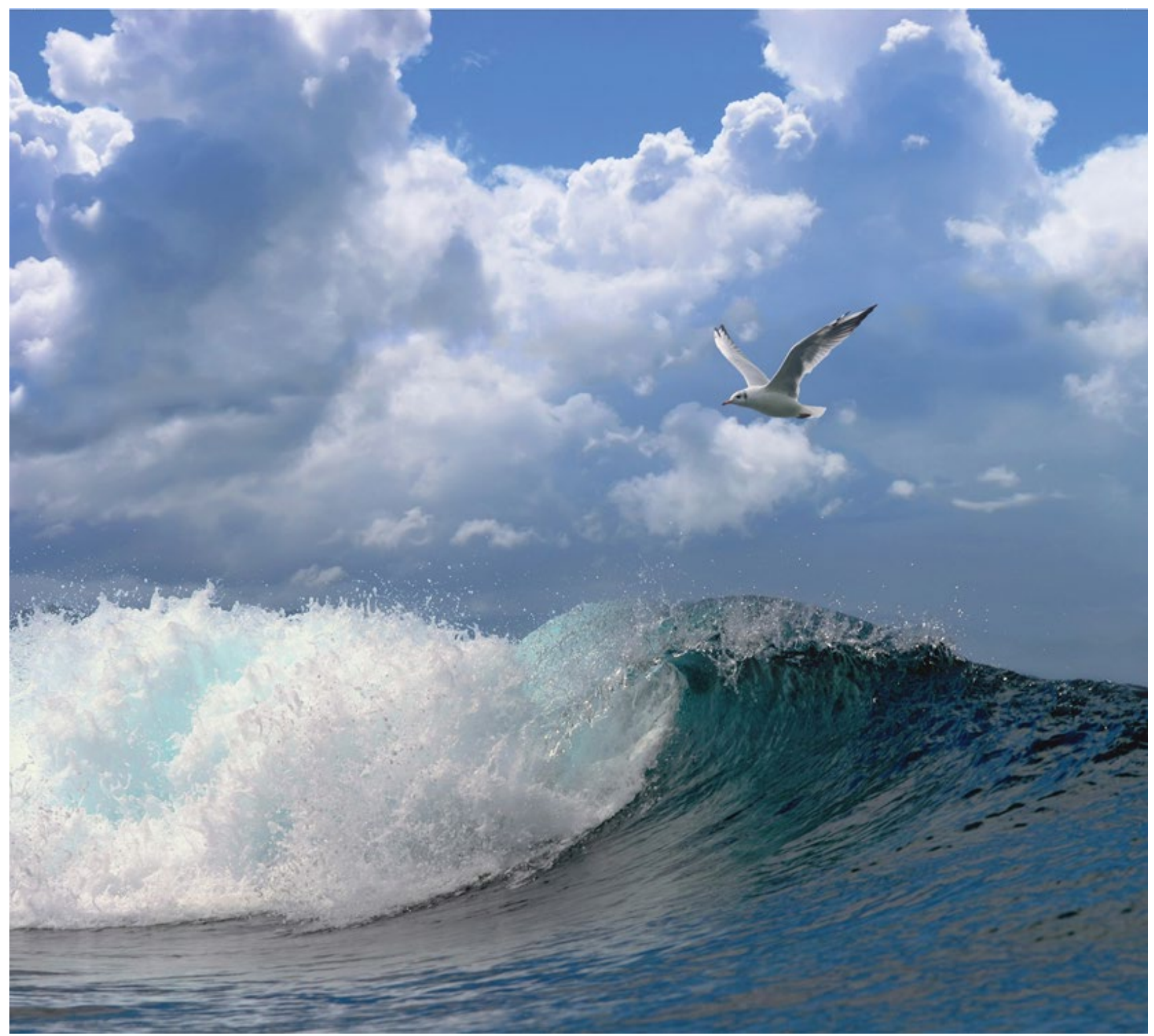

\title{
Inventory of potential new anti-fouling strategies inspired by nature
}




\section{Inventory of potential new anti-fouling strategies inspired by nature}

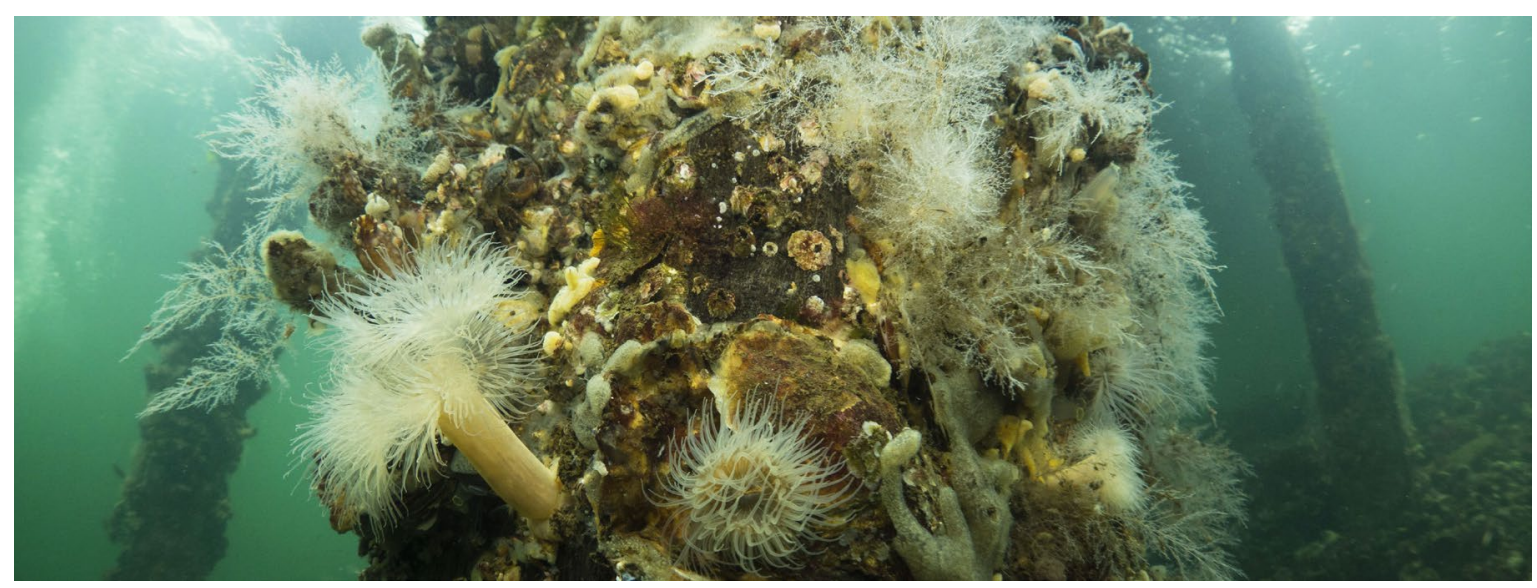

Picture by Oscar Bos, Wageningen Marine Research 
Inventory of alternative anti-fouling strategies inspired by nature. Wageningen, Wageningen Marine Research, Wageningen Marine Research report C048/19.

Client: Marin, Wageningen.

This research is funded from the TKI-allowance of the Dutch Ministry of Economic Affairs.

This report can be downloaded for free from https://doi.org/10.18174/477421.

Wageningen Marine Research is ISO 9001: 2015 certified.

(C) 2016 Wageningen Marine Research

Wageningen Marine Research, institute of Stichting DLO is registered in the Dutch trade record nr. 09098104, BTW nr. NL 806511618
The Management of Wageningen Marine Research is not responsible for resulting damage, as well as for damage resulting from the application of results or research obtained by Wageningen Marine Research, its clients or any claims related to the application of information found within its research. This report has been made on the request of the client and is wholly the client's property. This report may not be reproduced and/or published partially or in its entirety without the express written consent of the client. 


\section{Contents}

\section{Summary}

$\begin{array}{llr}1 & \text { Introduction } & 5\end{array}$

1.1 Re-Drag with Nature $\quad 5$

$\begin{array}{lll}1.2 & \text { Biofouling } & 6\end{array}$

$\begin{array}{lll}\text { 1.2.1 Fouling prevention with biocides } & 7\end{array}$

$\begin{array}{lll}\text { 1.2.2 Environmental friendly alternatives } & 8\end{array}$

2 Seaweeds and anti-fouling $r 9$

$\begin{array}{lll}2.1 & \text { Physical anti-fouling strategies } & 9\end{array}$

2.2 Chemical anti-fouling strategies $\quad 9$

2.2.1 Production of secondary metabolites by seaweeds $\quad 10$

2.2.2 Microbe symbiosis $\quad 12$

2.3 Application of seaweed strategies $\quad 12$

2.3.1 Physical anti-fouling strategies $\quad 12$

2.3.2 Examples of seaweeds anti-fouling compounds $\quad 12$

$\begin{array}{ll}\text { 2.3.3 Application in anti-fouling systems } & 13\end{array}$

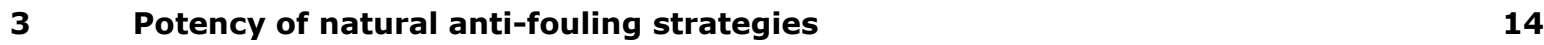

$\begin{array}{lll}3.1 & \text { Chemistry based anti-fouling } & 14\end{array}$

3.1.1 Seaweed strategies $\quad 14$

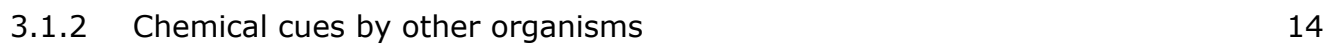

3.2 Physical based anti-fouling 15

$\begin{array}{lll}3.2 .1 & \text { Seaweed strategies } & 15\end{array}$

$\begin{array}{lll}3.2 .2 & \text { Flow velocity } & 15\end{array}$

$\begin{array}{lll}3.2 .3 & \text { Surface structure } & 16\end{array}$

$\begin{array}{lll}3.3 & \text { Symbiosis } & 17\end{array}$

$\begin{array}{llr}4 & \text { Conclusion } & 18\end{array}$

$5 \quad$ Quality Assurance $r$

$\begin{array}{lr}\text { References } & 20\end{array}$

$\begin{array}{lr}\text { Justification } & 24\end{array}$ 


\section{Summary}

As part of the Dutch Top consortia for Knowledge and Innovation (TKI) project 'Re-Drag with Nature' an inventory was made of the strategies that sea weeds apply to reduce the settlement and development of fouling organisms on their surface. This inventory was made based upon available literature and the results were assessed for their potency to protect man-made structures against biofouling. The reason for the focus on seaweeds was initiated by the observations that fouling pressure on seaweeds is in general low, and further supported by the knowledge that a lot of effort is currently being made to cultivate seaweeds and to utilise the compounds that can be extracted from it. However, the inventory was not fully limited to seaweeds. Where it inspired the thinking of new alternatives these were also briefly assessed.

Seaweeds make use of physical and chemical strategies to keep their surface free of biofouling organisms. The physical strategies are based on the continuous renewal of surface material and are, therefore, not considered applicable to protect man-made structures without continuous maintenance. Self-polishing coatings are available for ship hulls, but these are only effective in combination with biocides.

An alternative physical process that is not applied by seaweeds, but that may have the potency to reduce fouling is a combination of flow velocity and surface structure that could prevent early stages of fouling organisms from attaching to a surface. As this requires a controlled environment, it is not applicable to ship hulls or maritime infrastructure. It could work in industrial cooling water systems, but as the current methods that are applied there seem to fulfil the needs of the industry, this option was not further investigated.

The chemical anti-fouling strategies of seaweeds are based on the production of a broad range of metabolites with the potential to reduce settlement and/or development of fouling organisms. Although the effectiveness of several of these metabolites has been shown on experimental scale, commercial application of bio-based compounds for anti-fouling purposes does not seem attractive, due to the high costs that are related with legislation/registration procedures for new chemicals.

Apart from producing anti-fouling metabolites themselves, seaweeds can also support specific microbes that have little or no negative impact on their condition, but that prevent the settlement of more harmful species. A similar strategy, where a fouling species with low negative impact is favoured and supported, can have potential to manage fouling in an environmental friendly way on man-made surfaces where some drag is acceptable. As far as we are aware this is a completely new approach to deal with biofouling. When writing this report a proposal for a joint industry project (JIP) is being prepared that aims to investigate the potency of this approach to manage bio-fouling on offshore infrastructure. 


\section{Introduction}

\subsection{Re-Drag with Nature}

Re-Drag with Nature is a project initiated by MARIN and Wageningen Marine Research (WMR) and in part financed by the Dutch TKI-program. Endures and Wagenborg Shipping are involved as external partners. The overall aim of the project was to investigate whether it is possible to prevent fouling in an environmental friendly way and to predict the effect of fouling on the ship resistance and flow. This serves two overall goals: the development of a prediction model that enables the ship owner to find the optimal balance between fuel costs/emission and maintenance/cleaning costs. Secondly, the development of a new coating (principle) that prevents fouling in an environmental friendly manner.

The specific topics of the project were:

1. To investigate the influence of the structure of biofilms on resistance and the way to calculate/determine this.

2. To investigate the relation between local and climatological circumstances that influence the biofilm development on ship hulls and the effect on the fuel consumption.

3. To investigate whether the mechanisms of seaweed to protect itself from fouling can be used on ship hulls.

4. To set up a JIP and/or NWO-research programme to elaborate on the abovementioned three topics and come to significant steps in the maritime sector.

This report describes the outcome of topic 3 and indicates the related progress on topic 4 . The reason for the focus of topic 3 on seaweeds was initiated by the observations that fouling pressure on seaweeds is in general low, and further supported by the knowledge that a lot of effort is currently being made to cultivate seaweed and to utilise the compounds that can be extracted from it. 


\subsection{Biofouling}

Every hard substrate submerged in water will become subjected to biofouling. Biofouling is the consecutive accumulation of organic chemical compounds and bacteria which make up the primary film, primary colonizers (bacteria and diatoms), secondary colonizers (spores of seaweeds and protozoa) and tertiary colonizers (invertebrates like barnacles, mussels and tunicates). The primary and secondary colonizers roughly fall in the process called microfouling and the tertiary colonizers in the process called macrofouling, although micro- and macrofouling overlap slightly. See Figure 1 for a general overview of the biofouling process (Abarzua \& Jakubowski, 1995; Armstrong et al., 2000; Wahl, 1989).

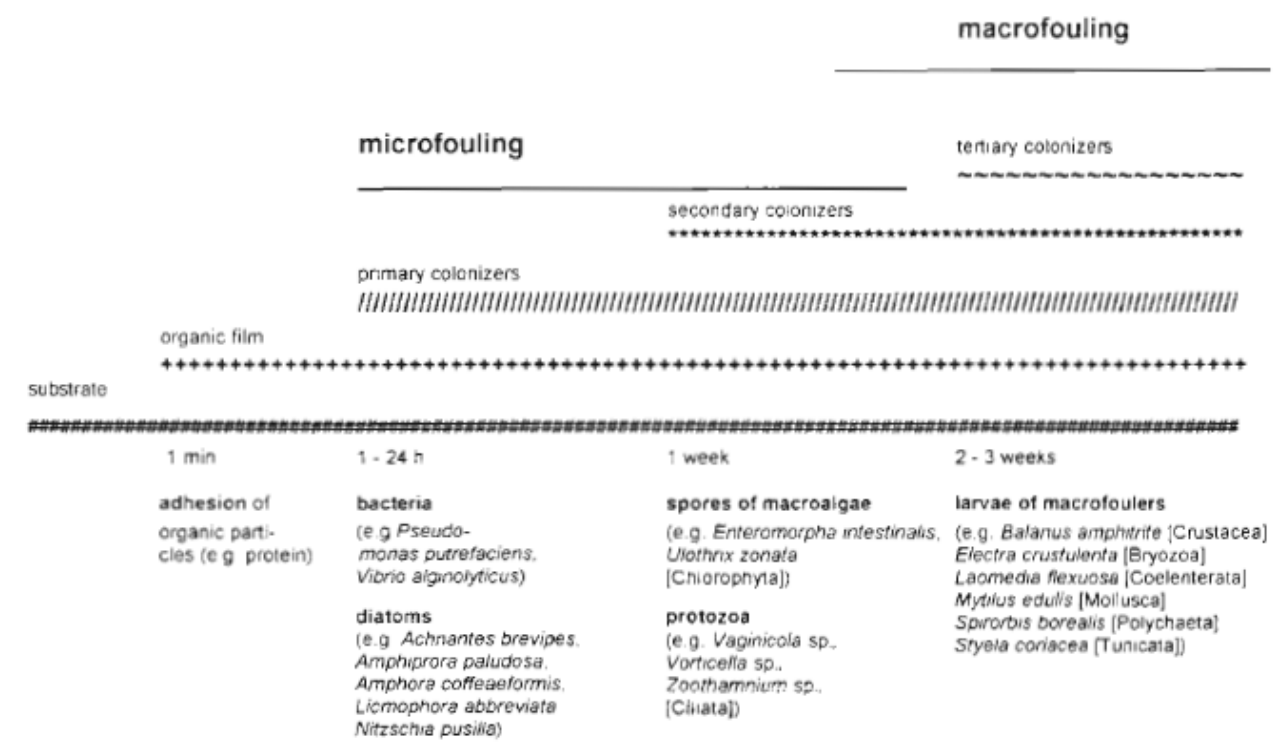

Figure 1 Successive accumulation during biofouling, from Abarzua \& Jakubowski, 1995.

Biofouling in the marine environment can have considerable economic and related environmental consequences. In the shipping industry, biofouling on the hull of a ship causes an increase in drag that results in an increase in fuel consumption and $\mathrm{CO}_{2}$ emission (Abarzua \& Jakubowski, 1995; Schultz et al., 2011). Furthermore, biofouling also can cause microbial induced corrosion of the ship's hull, increasing maintenance costs (Abarzua \& Jakubowski, 1995).

Apart from these consequences for the ship owners, vessels can also transfer unwanted (invasive) fouling organisms to other regions, which can have economic impact on a wider scale (ICES, 2019). Also for structures that are not moving, biofouling can have a negative impact. Not only by means of microbial induced corrosion (MIC) that can occur under layers of biofouling on steel surfaces (Little \& Lee, 2007), but a thick layer of fouling hampers the inspection of the integrity of structures, it adds weight and increases the impact of water currents on for instance the fundaments of offshore platforms. 


\subsubsection{Fouling prevention with biocides}

Since the beginning of shipping, systems have been developed to prevent biofouling of the submerged parts. The majority of these systems is currently based on the use of paints containing biocides, which are chemical compounds that are released from the paint matrix to induce a constant layer of biocide in the water to prevent biofouling (Amara et al., 2018). Historically, mostly tributyltin (TBT) and copper were used as active substance in anti-fouling paints. TBT was very effective and remained active in the paint for years (Armstrong et al., 2000; Omae, 2003), but turned out to be very toxic to numerous non-targeted marine species. Around 1970 it was already shown that TBT caused shell deformations and reproductive problems in the Pacific oyster Crassostrea gigas in France (Alzieu et al., 1986). Furthermore, imposex (male characteristics developing in females) in gastropods occurred at locations of high shipping activities, affecting more than 260 gastropod species (El Ayari et al., 2018). In combination with its persistence in sediments and bioaccumulation (Antizar-Ladislao, 2008), the environmental impact of TBT was substantial. This insight led to local bans on the use of TBT from 1980 onward and a global ban in 2008 .

Tributyl-tin paints are so called biocidal anti-fouling paints. These can be classified in three maintypes: (1) Conventional; insoluble matrix with microscopic pores to allow the biocide to be released, (2) Erodible; the matrix partially dissolves to release the biocide from the layers underneath, (3) Selfpolishing; hydrophobic paint matrix composed of the biocide linked to a polymer from which the biocide is released by hydrolysis followed by erosion of the now hydrophilic polymer residue (Gittens et al., 2013). Tributyl-tin paints fall in the last category.

Stimulated by the TBT-ban alternative anti-fouling compounds were becoming more widely used, often based on zinc and copper compounds (Yebra et al., 2004). Although these compounds are considered less harmful to the environment than TBT, similar problems with toxicity and accumulation seem to be evident from their use (Abarzua \& Jakubowski, 1995; Amara et al., 2018; Armstrong et al., 2000; Chen et al., 2017). For instance sea urchin (Paracentrotus lividus) embryos exposed to copper developed skeletal and gut abnormalities in their larvae stage (Gittens et al., 2013; Manzo et al., 2008). Zinc pyrithione (ZPT) seemed to be an environmental friendly alternative, because of its rapid photo degradability. But in the absence of light, it persists in the environment (Maraldo \& Dahllöf, 2004). Research showed its toxicity to zebrafish (Danio rerio) by causing growth retardation, tissue pathological and physiology alternations of organs (Zhao et al., 2018). Alternatives based on organic biocides like Sea-Nine ${ }^{\mathrm{TM}} 211$ and Irgarol 1051@ (2-methylthio-4-t-butylamino-6-cyclopropylamino-striazine) showed similar features. In fact Sea-Nine 211 was shown to be more toxic to sea urchin eggs and embryos than tributyltin oxide (TBTO) (Kobayashi \& Okamura, 2002). 


\subsubsection{Environmental friendly alternatives}

The above indicates the need for anti-fouling systems that are not based on toxic compounds. One approach was to prevent fouling organisms to settle or adhere by making the surface incompatible to attach to or preventing permanent adhesion (Gittens et al., 2013; Nir \& Reches, 2016). Other examples are:

-low surface-energy fouling-release coatings, which cause micro foulers to be released from the hull of a ship by shear stress due to the ships movement, because they cannot attach sufficiently to the ship's hull due to the low surface tension;

-polymer brushes; and

-sol-gel coatings (Gittens et al., 2013).

However, none of these alternatives are as effective as the old tributyltin based coatings were. Therefore, there is still a need for effective environmental friendly methods to prevent biofouling and research on the use of natural compounds with anti-fouling properties is ongoing. These natural antifouling compounds can originate from organisms like bacteria, sponges, fungi, microalgae, and seaweeds.

Chemical anti-fouling compounds should preferably work via chemical signalling for the specific target organisms instead of being toxic for non-target species (Almeida \& Vasconcelos, 2015; Hellio et al., 2002). To introduce such compounds onto the market, "In line with the Biocidal Product Regulation (EU) 528/2012, a clear description of the mode of action, biological targets and environmental fate..." is required (Almeida \& Vasconcelos, 2015). This is a costly and time consuming procedure. 


\section{Seaweeds and anti-fouling}

It is clear that marine organisms are not completely free of biofouling. For instance, certain species of barnacles are capable of attaching to whales (Seilacher, 2005) and the blue mussel Mytilus edulis often settles on filamentous algae (Dobretsov, 1999). However, the degree of biofouling on marine organisms differs from that on non-living surfaces. The later stages of biofouling, such as macro fouling, often do not occur and the degree of biofouling differs between organisms (Armstrong et al., 2000). Certain species of marine seaweeds are very effective in protecting themselves from biofouling (Armstrong et al., 2000; Bhadury \& Wright, 2004; Brock et al., 2007; Dahms \& Dobretsov, 2017; Walters et al., 1996; Wikström \& Pavia, 2004). They need to be, since coverage by fouling organisms may decrease photosynthesis and increase dragforces causing the algae to be dislodged from the bottom (Davis et al., 1989).

Seaweeds can use physical and chemical strategies, alone or in combination to reduce the impact of biofouling, as summarised below.

\subsection{Physical anti-fouling strategies}

Some seaweed species are very effective in protecting themselves from biofouling by physical strategies. They can continuously shed the outer layer of cells and mucilaginous cover to release fouling organisms from their leafs and prevent accumulation of these organisms (Armstrong et al., 2000; Halat et al., 2015; Nylund \& Pavia, 2005). Up to $25 \%$ of the frond epidermis can be shed per week (Halat et al., 2015).

Furthermore, Laminaria species and seagrass can shed the distal ends of their blades to remove fouling organisms (Armstrong et al., 2000; Mann, 1973). Since the meristem is located at the base of the blade, they can continue growing even if the distal blade is lost (Rolin et al., 2017).

\subsection{Chemical anti-fouling strategies}

Another method applied against biofouling is chemical in nature. Marine organisms can secrete socalled biogenic compounds in the water to defend themselves against a variety of fouling organisms like bacteria, algae, fungi, protozoa or macrofoulers (Abarzua \& Jakubowski, 1995; Bhadury \& Wright, 2004). These biogenic compounds are secondary metabolites produced for protection and thus not essential for life (Abarzua \& Jakubowski, 1995). Up to now, already a wide range of these biogenic compounds has been identified and purified, such as lactones, furanes, peptides, phenols, carotenoids, alkaloids and terpenoids (Almeida \& Vasconcelos, 2015; Bhadury \& Wright, 2004).Seaweeds also make use of this strategy and secrete secondary metabolites in order to, among other things, prevent biofouling on their surfaces. These secondary metabolites are often seasonally produced and can be produced at different live stages of the seaweeds (Khfaji \& Boney, 1979; Rickert et al., 2016; Saha \& Wahl, 2013). Furthermore, these compounds can work on different levels of the biofouling process (Hellio et al., 2001a). The active metabolites can either be produced and excreted by the seaweed itself or by symbiotic micro-organisms. 


\subsubsection{Production of secondary metabolites by seaweeds}

The secondary metabolites produced by seaweeds can, on a microbial level, provide protection against pathogens, prevent microbe-induced premature decomposition and inhibit the formation of a bacterial biofilm (Dobretsov et al., 2011; Engel et al., 2006; Puglisi et al., 2007). These secondary metabolites can be produced continuously or only when the seaweeds comes into contact with the target organisms and its chemical signals (Amsler \& Fairhead, 2005). An overview of compounds with antimicrobial and anti-fouling properties found in microalgae is presented in Table 1 (Goecke et al., 2010).

An example is the algae Bonnemaisonia hamifera whose extracts have been shown to inhibit growth of bacteria in a laboratory scale study, at compound concentrations naturally produced on the surface of the algae. This indicates that $B$. hamifera can control the bacterial growth on its surface by producing growth-inhibiting biogenic compounds (Nylund et al., 2005).

Another, extensively researched, example is the benthic marine macro algae Delisea pulchra from the class Rhodophycaea, that secretes a class of secondary metabolites called halogenated furanones or fimbrolides. This class of secondary metabolites acts as an antagonist of the acylated homoserine lactone $(\mathrm{AHL})$ regulatory system inhibiting the quorum sensing (QS) of bacteria. Quorum sensing is "a cell-cell communication and gene regulatory mechanism that allows bacteria to coordinate swarming, biofilm formation, stress resistance, and production of toxins and secondary metabolites in response to threshold concentrations of QS signals that accumulate within a diffusion-limited environment." (Dobretsov et al., 2009). By inhibiting QS the halogenated furanones inhibits bacterial colonization and thus biofilm formation on the surface of the seaweeds (Defoirdt et al., 2004; Dworjanyn et al., 1999; Hentzer et al., 2002; Manefield et al., 2002). One example of the effect of these halogenated furanones is the research by Ren et al. (2002) where they showed that a furanone can prevent the bacterium Bacillus subtilis from forming a biofilm and inhibits its swarming motility (Ren et al., 2002). Besides a number of other benefits achieved by preventing the accumulation of microbes (no increase of hydrodynamic drag, no reduced buoyancy and elasticity of tissue, no grazers attracted, and no nutrient loss to bacteria (Goecke et al., 2010)), it works as an anti-fouling method by preventing the successive settlement of micro- and macrofoulers (Denys et al., 1995; Hellio et al., 2001a; Kupper et al., 2001; Manefield et al., 2002; Nylund et al., 2005; Othmani et al., 2016).

The secondary metabolites produced by seaweeds can also directly work as anti-fouling compounds against secondary and tertiary colonizers. They can be lethal, inhibit settlement or inhibit the growth of the settling organism (Brock et al., 2007; Dworjanyn et al., 2006; Hellio et al., 2002; Walters et al., 1996; Wikström \& Pavia, 2004). An example is the secretion of waterborne metabolites, primarily phlorotannins, by the brown seaweed Fucus vesiculosus, which inhibits the settlement of the barnacle Balanus improvisus (Brock et al., 2007; Wikström \& Pavia, 2004). It was shown in the research by Brock et al. (2007) that the phlorotannin levels of $F$. vesiculosus could, under natural conditions, reach concentrations high enough to inhibit barnacle larvae settlement (Brock et al., 2007). Another example are meroditerpenoids produced by the macro alga Cystoseira baccata that inhibit the enzyme phenoloxidase. This enzyme is necessary in the production of mussel byssal thread plaques. The meroditerpenoids, therefore, inhibit the adhesion of mussel larvae to the algal surface (Mokrini et al., 2008). Some species like the red alga Delisea pulchra produce compounds that are effective against a whole range of fouling organisms. 
Table 1

List of antimicrobial and anti-fouling compounds found in seaweeds; Table 5 from Goecke et al., 2010. AV = antiviral, $A E=$ anti-fouling, $A F=$ antifungal activity, $G N I=$ antibiotic activity against Gram-negative bacteria, GPI = antibiotic activity against Gram-positive bacteria.

\begin{tabular}{|c|c|c|c|}
\hline Macroalga & Compounds & Activity & Source \\
\hline \multicolumn{4}{|l|}{ Chlorophyta } \\
\hline Avrainvillea nigricans & 5'-hydroxy isoavrainvilleol & GPI & Colon et al. (1987) \\
\hline Caulerpa spp. & Sesquiterpenoids & GPI, GNI & Paul et al. (1987) \\
\hline Codium iyengarï & Iyengaroside-A, clerosterol galactoside & GPI, GNI & Ali et al. (2002) \\
\hline Penicillus capitatus & Capisterones A, B & $\mathrm{AF}$ & Puglisi et al. (2004) \\
\hline Tydemania expeditionis & Sulphated triterpenoids & $\mathrm{AF}$ & Jiang et al. (2008) \\
\hline Ulva fasciata & Labdane diterpenoids & GNI & Chakraborty et al. (2010) \\
\hline \multicolumn{4}{|l|}{ Heterokontophyta, Phaeophyceae } \\
\hline Canistrocarpus cervicornis & Diterpenes & $\mathrm{AE}$ & Bianco et al. (2009) \\
\hline Cystoseira spinosa var. squarrosa & Tetraprenyltoluquinol & GPI, GNI & Amico et al. (1988) \\
\hline Cystoseira tamariscifolia & Methoxybifurcarenone & GNI & Bennamara et al. (1999) \\
\hline Dictyotaceae & Dolabellane derivatives & $\mathrm{AF}$ & Tringali et al. (1986) \\
\hline Dictyopteris zonarioides & Zonarol \& isozonarol & $\mathrm{AF}$ & Fenical et al. (1973) \\
\hline Dictyota menstrualis & Dictyol D, pachydictyol A & $\mathrm{AE}$ & Schmitt et al. (1995) \\
\hline Dilophus guineensis & Dilophic acid & GPI & Schlenk \& Gerwick (1987) \\
\hline Dilophus okamurai & Spatane-type diterpenes & $\mathrm{AE}$ & Kurata et al. (1988) \\
\hline Fucus vesiculosus & Polyhydroxylated fucophlorethol & GPI, GNI & Sandsdalen et al. (2003) \\
\hline Landsburgia quercifolia & 1,4-naphthoquinone & GPI, AF & Perry et al. (1991) \\
\hline Lobophora variegata & Lobophorolide & $\mathrm{AF}$ & Kubanek et al. (2003) \\
\hline Sargassum spp. & Polyphenols & $\mathrm{AE}, \mathrm{GNI}$ & Sieburth \& Conover (1965) \\
\hline Stoechospermum marginatum & Spatane diterpenoids & GPI & De Silva et al. (1982) \\
\hline Stoechospermum marginatum & Sulfated fucan & AV & Adhikari et al. (2006) \\
\hline \multicolumn{4}{|l|}{ Rhodophyta } \\
\hline Asparagopsis armata & Halomethanes, haloether, haloacetales & GPI, GNI & Paul et al. (2006) \\
\hline Bonnemaisonia hamifera & Poly-brominated 2- heptanone & GNI & Nylund et al. (2008) \\
\hline Callophycus serratus & Bromophycolides & $\mathrm{AF}$ & Lane et al. (2009 \\
\hline Dasya pedicellata var. stanfordiana & P-hydroxybenzaldehyde & GPI, GNI & Fenical \& McConnell (1976) \\
\hline Delesseriaceae & Almazole D & GNI & N'Diaye et al. (1996) \\
\hline Delisea pulchra & Halogenated furanones & $\mathrm{AE}$ & Maximilien et al. (1998) \\
\hline Delisea pulchra & Halogenated furanones & GPI, GNI & Wright et al. (2006) \\
\hline Grateloupia indica & Galactan sulphate & AV & Chattopadhyay et al. (2007) \\
\hline Laurencia chilensis & 3-hydroxi-4-methyl acetophenone & GPI, GNI & Valdebenito et al. (1982) \\
\hline Laurencia majuscula & Brominated sesquiterpenes & GPI, GNI & Vairappan et al. (2010) \\
\hline Laurencia pannosa & Pannosanol, pannosane & GNI & Suzuki et al. (2001a) \\
\hline Laurencia spp. & Laurinterol, isolaurinterol & GNI & Vairappan et al. (2001b) \\
\hline Laurencia spp. & Brominated sesquiterpenes & GPI, GNI & Bansemir et al. (2004) \\
\hline Osmundaria serrata & Lanosol ethyl ether & GPI, GNI, AF & Barreto \& Meyer (2006) \\
\hline Rhodomela confervoides & Bromophenols & GPI, GNI & $\mathrm{Xu}$ et al. (2003) \\
\hline Sphaerococcus coronopifolius & $\begin{array}{l}\text { Bromosphaerone, } \\
\text { 12S-hydroxybromosphaerodiol }\end{array}$ & GPI & Etahiri et al. (2001) \\
\hline
\end{tabular}

To prove the anti-fouling properties of the produced secondary metabolites, it is necessary to show that the compound(s) is (are) naturally found in sufficient concentrations on the surface of the organism. This method was developed by De Nys et al. (1998) who were able to extract non-polar (hexane-soluble) compounds from the surface of algae without destroying the algal surface cells, thereby accurately measuring the compound concentrations on the surface of the plant. The furanones are typically present at about $100 \mathrm{ng} \mathrm{cm}^{-2}$ on the surface of D. pulchra (Dworjanyn et al., 2006). They are produced in vesicles in specialised gland cells, mostly found amongst the cortical cells of the plant (Dworjanyn et al., 1999). It has been shown that the natural occurring concentrations of the furanones can inhibit the settlement of the green seaweed Ulva sp., red algae Ceramium sp., red algae Polysiphonia sp. and the brown alga Ectocarpus siliculosus (Denys et al., 1995; Dworjanyn et al., 2006). The function of other compounds on the surface of $D$. pulchra, like lipids, is unclear. It is hypothesized that these lipids help with the even spread of the furanones over the plants surface. A lipid matrix on the plant's surface may also prevent rapid degradation or dissolution of the furanones in the water (Dworjanyn et al., 2006) 


\subsubsection{Microbe symbiosis}

Instead of producing secondary metabolites to prevent biofouling itself, some seaweeds form symbiotic relationships with microbes (Goecke et al., 2010; Satheesh et al., 2016). Seaweeds in nature are generally colonized by an array of microbes (Wahl et al., 2012). The distribution of these microbes on the surface of seaweeds indicates that it is not due to fouling but mediated by the seaweeds itself (Armstrong et al., 2000; Armstrong et al., 2001; Campbell et al., 2015; Dobretsov et al., 2006). The bacterial communities of seaweeds are often highly specific and their composition differs from that occurring in the surrounding seawater (Goecke et al., 2010). Although the benefits for either partner in such a symbiosis is not always known, it is assumed that the benefits for microbes are nutritional in nature (Bonar et al., 1986) and give them an advantageous position over other microbes (Armstrong et al., 2000), while the benefit for the seaweeds is protection against micro- and macrofoulers (Satheesh et al., 2016; Wahl et al., 2012). It has been found that microbes associated with microalgae produce secondary metabolites that can inhibit the settlement of other marine organisms. This has been studied extensively and for many marine organisms, like sponges, corals, seaweed. Satheesh et al. (2016) provide an extensive overview of the research done into the macro organisms-microbe relationship. An example is the finding of a new species of the marine bacterial genus Pseudoalteronomas, associated with the marine alga Ulva lactuca, which exhibits antifouling properties (Egan et al., 2001a). A similar finding was the production of an anti-algal peptide by the bacterium Pseudoalteromonas tunicata, found on the alga Ulva australis, which inhibits spore germination (Egan et al., 2001b). The actual defence against biofouling is thus chemical in nature.

\subsection{Application of seaweed strategies}

\subsubsection{Physical anti-fouling strategies}

The constant renewal and shedding of the surface area that seaweeds apply as strategy to remove fouling organisms is considered not applicable in practice to protect man-made objects. Although technically possible, it would require too thick coating layers and/or too frequent maintenance to be protective for longer periods.

\subsubsection{Examples of seaweeds anti-fouling compounds}

To evaluate the anti-fouling effectiveness of a new compound versus its toxicity, the $\mathrm{LC}_{50} / \mathrm{EC}_{50}$ quotient, or therapeutic ratio, is used. The $\mathrm{LC}_{50}$ being the $50 \%$ lethal concentration for the test organisms and the $\mathrm{EC}_{50}$ the effective concentration that inhibits $50 \%$ of the biological activities of the test organism (Almeida \& Vasconcelos, 2015; Gittens et al., 2013). Values of the LC $_{50} / \mathrm{EC}_{50}$ quotient higher than 15 indicate a possible non-toxic anti-fouling compound, while much higher values indicate suitable anti-fouling compounds for commercial use (Almeida \& Vasconcelos, 2015; Qian et al., 2010).

Different researchers have shown the anti-fouling properties of compounds extracted from a wide variety of seaweeds. Salama et al. (2018) studied the anti-fouling activity of extracts of three macro algal species, Chaetomorpha linum, Turbinaria ornata, and Sargassum polycystum, against barnacle larvae in both a laboratory assay using Petri dishes and in a field study by mixing the crude seaweeds extracts with varnish, coating nylon net panels and hanging them for 3 months submerged in the Red sea. All three methanol extracts inhibited the settlement of cypris larvae in the laboratory study. In the field, only the extracts of T. ornata and S. polycystum significantly reduced biofouling. Analyses showed that the crude extracts contained fatty acids, their derivatives phytosterols and terpenoids, and some other compounds. The results from this study indicate that crude algal extracts could be used as natural anti-fouling compounds in anti-fouling paints, although toxicity testing of these crude extracts is necessary (Salama et al., 2018).

Another study tested crude ethanol extracts from the red alga Chondrus crispus. The dried extracts had more anti-fouling activity against marine bacteria and other microfoulers, while the fresh extracts 
had more anti-fouling activity against macrofoulers. They also tested the anti-fouling properties of the dried extracts in a field study by dissolving $1 \%$ dried algal extract in a controlled depletion polymer paint, coating primer-coated steel coupons and submerging them into the sea in Southampton (UK) for 3 months (April-July). It was shown that for a period of 10 weeks the paint with the dried algal extract had lower fouling than the negative control (blank panel) and the positive control (same coating with biocide chlorathalonil) (Chambers et al., 2011).

The brown algae Bifurcaria bifurcata, Halidrys siliquosa, Halopteris scoparia, Dictyopteris membranacea, Bifurcariopsis capensis, Cladostephus verticillatus and Bifurcaria brassicaeformis have been shown to have anti-fouling activity against several marine bacteria and fungi, but low toxicity against the larvae of marine invertebrates (Hellio et al., 2000). Bifurcaria bifurcata has been shown to have antimicrobial activity against two marine bacteria, Cobetia marina and Pseudoalteromonas haloplanktis, which showed seasonal variation with the highest level of activity between April and August. Furthermore, concerning the effectivity of $B$. bifurcata extracts towards adhesion and toxicity of the barnacle $B$. amphitrite cypris larvae, the $\mathrm{EC}_{50}$ of settlement was lowest in the period April to July (reduced settlement at $>5 \mu \mathrm{g} / \mathrm{ml}$ ). However, the $B$. amphitrite nauplii larvae toxicity test showed that the April to August extracts were toxic to nauplii with the extracts from May $\left(L_{50}=55.6 \mu \mathrm{g} / \mathrm{ml}\right)$ and June $\left(L C_{50}=38.3 \mu \mathrm{g} / \mathrm{ml}\right.$ ) being the most toxic. Even so, for the other months the $L_{50}$ is much higher than the $\mathrm{EC}_{50}$. This indicates that for some months the active fractions of $B$. bifurcata extracts are effective against B. amphititre larvae settlement and marine bacteria growth (Marechal et al., 2004).

Hellio et al. studied the anti-fouling effectivity of compounds from numerous brown algae, like Bifurcaria, against fungi, bacteria, diatoms, seaweeds and the blue mussel. They found numerous compounds, like diterpenoid compounds and some pure molecules, with anti-fouling and antimicrobial activity (Hellio et al., 2001b). They performed a similar experiment in 2002 with extracts from thirty algae, finding twelve promising extracts with high anti-fouling activity and low toxicity against invertebrate larvae (Hellio et al., 2002).

Othmani et al. tested eight compounds extracted from the brown seaweed Taonia atomaria for their anti-fouling activity against five marine bacteria and two barnacle species. The same two barnacle species were used for toxicity testing. They found one compound, (-)-gleenol, which could be a new anti-fouling compound because of its low $\mathrm{EC}_{50}$ and moderate toxicity (Othmani et al., 2016).

More seaweeds compounds can be found in Bhadury \& Wright, 2004; Dahms \& Dobretsov, 2017; and Fusetani \& Clare, 2006.

\subsubsection{Application in anti-fouling systems}

Around the year 2000 the BRITE/EURAM 3 Project was conducted within the Fourth Framework Programme of the European Community, with the aim to develop environmentally compatible antifouling coatings for the protection of ships, water systems, fish cages, and other immersed structures against aquatic growth. One part of the project consisted of synthesizing 204 compounds that fall into four different classes of biocide compounds. The composition of these compounds was tested using laboratory barnacle bioassays and microbiological assays. Sixteen of the most promising compounds were used for further testing. These tests were: static exposure of panels with model paints in the North Sea and Mediterranean, anti-barnacle properties of paints by laboratory assays, and environmental tests specially developed to seawater conditions. In the end, by combining all these results with physical and economical properties, there were three different (groups of) compounds that were considered promising for further development in coatings and patenting. The compound CAULB13 appeared to be the most promising one and was, therefore, tested on various rafts and ships. This compound was shown to have "...satisfactory anti-fouling properties up to 26 months; relatively low toxic effects on non-target organisms; appropriate water solubility; simple synthesis and cheap, readily available starting material for synthesis; good compatibility with other paint constituents; good thermal stability." (CORDIS BRPR960159, 2001). 


\section{Potency of natural anti-fouling strategies}

\subsection{Chemistry based anti-fouling}

\subsubsection{Seaweed strategies}

The literature review shows that seaweeds produce numerous compounds to prevent biofouling of their surface and that these compounds can be extracted and applied in coatings that reduce biofouling in both laboratory and field settings. Despite this, we are not aware of any commercially available anti-fouling coatings that are based on these substances. It is suggested that this is due to insufficient funding for this type of R\&D research and (therefore?) a lack of strong incentives for scientists from different disciplines to fully commit themselves to these goals (Qian et al., 2010). If this is really the case, it suggests that until now it has not been found economically feasible to invest in the development of bio-based anti-fouling products.

The large-scale production of the natural anti-fouling compounds for a price or at a scale that is attractive for commercial companies to invest in is a major challenge (Qian et al., 2010). Preferably, the active compounds are produced by direct extraction from marine macro-organisms that are harvested from mariculture farms. The increasing interest in seaweed farming might result in a more steady flow of natural basis material, but the isolation of specific compounds from marine algae is still very expensive and time consuming (Dahms \& Dobretsov, 2017). The use of combinatorial genetic or metabolic engineering, or hybrids, might be a solution to this problem in the future (Bhadury $\&$ Wright, 2004), but at this moment chemical synthesis still is a better option.

Apart from the challenge of making the production profitable, the registration of the active compound as a new biocide before it is allowed to the market is a serious hurdle to be overcome. This requires the time consuming and costly development of an environmental risk assessment dossier describing the half-life, breakdown, environmental fate, toxicity and other possible negative environmental impacts of the new compound (Qian et al., 2010). Together with the costs that are always involved in R\&D this probably holds back investments in the development of bio-based anti-fouling coatings.

\subsubsection{Chemical cues by other organisms}

The chemistry based anti-fouling strategy that is applied by seaweeds, the production of secondary metabolites that repel fouling organisms, is also used by many other organisms. The chances and limitations are comparable and, therefore, not further discussed here.

Biochemical signals do, however, also play a role in the development of a fouling community. For instance in the succession from the early colonisers bacteria, diatoms and protozoa that attracts the larvae of the invertebrate tertiary colonizers like barnacles, mussels, tubeworms etc. (Abarzua \& Jakubowski, 1995). Settlement of the tubeworm Hydroides elegans for instance is strongly induced by the presence of diverse biofilms, including those that consist of monocultures of bacteria. This suggests that the larvae are able to detect the presence of extracellularly polymers that are secreted by the early colonisers (Lam et al., 2003).

Bivalves of various species also respond to trophic cues for the settlement of larvae (Forêt et al., 2018). Larval settlement is influenced by saturated fatty acids, possibly linked to organic detritus and bacterial production deriving from terrestrial inputs. This implies that recruits of bivalves tend to settle in areas with more food availability (Leal et al., 2018). A similar positive cue is described for the blue mussel (Mytilus edulis) (Scott et al., 2016).

The presence of other species can also form a negative settlement cue. This was shown in an experimental set-up with larvae of the blue mussel that were allowed to choose between regions that were treated with an extract of crabs, a major predator of juvenile mussels and regions treated with extract of their food (algae). The latter clearly induced settlement of the larvae, while few larvae settled in regions treated with crab extract (Scott et al., 2016). 
Settlement cues can also come from individuals of the same species. The larvae of the tubeworm Hydroides elegans only metamorphose in presence of chemical cues produced by conspecifics. Without these cues, the larvae remain planktonic and will not settle (Bryan et al., 1997).

A similar mechanism has been described for barnacles, that secrete a so-called settlement-inducingprotein-complex (SCIP). This stimulates a clustered settlement, which increases the reproductive chances of the group. While low concentrations of SCIP stimulate settlement, higher concentrations have the opposite effect to avoid overpopulation of an area (Kotsiri et al., 2018).

It seems obvious that such negative settlement cues are highly species specific. Therefore, these substances probably have less potential as a general anti-fouling compounds. But even if this is not the case the production and registration of such substances will hold the same challenges as described above for the application of seaweed related metabolites for the same purpose.

\subsection{Physical based anti-fouling}

\subsubsection{Seaweed strategies}

The only known physical strategy applied by seaweeds to prevent biofouling, the constant renewal fouled material, seems not directly applicable to protect man-made structures without continuous effort and costs.

However, settling of fouling organisms is affected by physical conditions such as local flow velocity and surface and the following paragraphs contain an inventory of these conditions for the main groups of fouling organisms, seaweeds, tubeworms, barnacles and mussels.

\subsubsection{Flow velocity}

New surfaces are colonized by fouling organisms mainly through settlement of pelagic larvae. Successful settlement is only possible at relatively low flow velocities that allow the organisms to make contact with the substrate.

Cyprid larvae of the striped barnacle Amphibalanus amphitrite showed highest settlement rates in a tube with free stream velocity between $3-15 \mathrm{~cm} / \mathrm{s}$ (Qian et al., 1999). The researchers noted that the swimming capability of an organism heavily affects their rate of attachment. Recent research looked more into detail and showed that cyprid larvae of the bay barnacle (Balanus improvises) can make use of small time-windows of relative lower flow speeds near the substrate surface that are caused by turbulence (Larsson et al.,2016). A local flow velocity of $1.9-2.4 \mathrm{~cm} / \mathrm{s}$, that occurred only for 0.14 seconds was sufficient for these larvae to settle. This situation appeared near the boundary layer due to turbulence at a free-stream velocity of $20 \mathrm{~cm} / \mathrm{s}$.

Furthermore, they found that the cyprid's swimming speed was approximately $1.8 \mathrm{~cm} / \mathrm{s}$, explaining the critical local flow velocity, as they swim against the current (negative rheotaxis) to became almost stationary (Larsson et al., 2016).

It seems obvious that a similar mechanism applies for all fouling animal species.

In addition, the larvae of the blue mussel (Mytilus edulis) initially settle at locations with reduced flow velocity. However, after the first growth, they can detach and move to places with higher flow velocity and better food availability (Dobretsov \& Wahl, 2007).

For the tubeworm Hydroides elegans the highest settlement has been reported in free-flow velocities of 1 to $3 \mathrm{~cm} / \mathrm{s}$. At $10 \mathrm{~cm} / \mathrm{s}$ settlement was only 20\% (Qian et al., 1999).

The examples mentioned above indicate that biofouling can be prevented by maintaining a high flow velocity for all times. Logically this strategy is not possible to protect a ship's hull or a static maritime structure. It could in theory be applied to prevent fouling in cooling water circuits if these could be constructed in a way that turbulence will be avoided. In practice, this seems a difficult and probably impossible task. 


\subsubsection{Surface structure}

As the settling larvae have to get a hold on the substrate, a completely smooth surface reduces the attachment strength of fouling organisms. A more or less structured surface facilitates the development of a community of fouling organisms. However, the preferred texture can differ per species.

Cyprids of Amphibalanus amphitrite seem to prefer sinusoidal linear textures, with a distance below 32 $\mu \mathrm{m}$ for the sinusoidal shapes (Aldred et al., 2010). They seem to avoid ranges of 64-256 $\mu \mathrm{m}$, while again preferring larger distances of $512 \mu \mathrm{m}$. It is hypothesized that the size of the cyprid and its attachment organs are of critical importance for these size-ranges. At sinusoidal textures with a distance of $32 \mu \mathrm{m}$ or smaller, the attachment organs can easily connect with the surface. At slightly larger textures, the attachment organs are placed at curved angles, making their attachment weaker, while at even larger distances $(256 \mu \mathrm{m})$, the gaps between the sinusoidal structures are roughly half that of the size of the cyprid, making it hard for it to angle itself for proper attachment. At very large distances (>512 $\mu \mathrm{m}$ ), the cyprid can fit between the sinusoidal shapes, giving it a strong attachment. For this reason, preferred structures of certain substrates will highly differ between species of different sizes.

Zoospores of the species Ulva linza and Ulva compressa prefer surfaces with grooves that they can squeeze into, meaning roughly their own diameter or slightly smaller (Callow et al., 2002). More precisely, the zoospores of $U$. linza, are $5 \mu \mathrm{m}$ and prefer grooves of $5 \mu \mathrm{m}$. The researchers suggest that in valleys or grooves with a width that is less than twice the radius of the (spheroid) organism, the contact surfaces of adhesion become contact 'points', minimizing adhesion strength. However, the zoospores perform amoeboid-like space-filling movement, which makes the shape of the attached spore being partly determined by the availability of space. The zoospores also clearly choose their location to be most beneficial to them, since non-living beads of a similar shape and size dropped on the same surface did not aggregate in the same way as the zoospores did.

For the mussel Mytilus galloprovincialis, it was found that settlement on heterogeneous surfaces was preferred. More specifically, there was an avoidance of a homogenous ridged surface with a uniform distance of 1-2 $\mathrm{mm}$ between ridges with a mean depth of $1.5 \mu \mathrm{m}$ (Scardino et al., 2003). In addition to the preference of the blue mussel and pearl oyster for heterogeneous surfaces, Kobak (2001) found that zebra mussels preferred dark, shaded substrate.

In contrary to the previous groups, physical surface parameters seem of minor importance to the fouling tubeworm Hydroides elegans (Lam et al., 2003).

Based on the above it could thus be possible to produce a specific surface structure to reduce fouling of specific species, although it might not be possible to create a surface structure that prevents settlement of all unwanted species. 


\subsection{Symbiosis}

Seaweeds can live in symbioses with microbes that produce substances that prevent fouling of other organisms.

Symbiotic interactions are by definition not possible with non-living (man-made) structures, however, it might be possible to create conditions at the structure's surface that benefits fouling species with low negative impact, just like seaweeds that facilitate the development of micro-organisms that produce metabolites that prevent the settlement of less wanted fouling species.

This would be a new way to deal with biofouling: Instead of fighting the constant battle against fouling organisms which until now has been tried, one could also try to manage the fouling community in such a way that it is dominated by species with low impact.

The ideal 'low impact species' on men made structures:

1) add little water resistance to the surface;

2) do not develop high biomass;

3) have no negative impact on the integrity or durability of the structure /does not promote microbial induced corrosion;

4) prevents settlement of other, less preferred, species;

With these characteristics in mind, inspection videos of the underwater construction from various offshore platforms in the North Sea were analysed. This revealed at least one candidate species that seems to meet the qualifications of a 'low impact species'.

This approach by definition allows the settlement of the preferred fouling organism at the surface. As this will result in increased drag, it may be less useful for application on a ship's hull. In addition it will be very difficult if not impossible to maintain the conditions that favour the preferred fouling species above others on a ship's hull that is traveling between regions. On static infrastructure, however, it could be an alternative approach to reduce the impact of fouling, without the application of toxic agents. 


\section{Conclusion}

Seaweeds make use of physical and chemical strategies to keep their surface free of biofouling organisms that can negatively affect their conditions.

The physical strategies that are applied by seaweeds are not considered applicable to protect manmade structures as it needs continuous renewal of the surface material.

Other physical anti-fouling strategies that were explored are flow velocity and surface structure. Combined these aspects may have the potency to prevent fouling. However, this requires a controlled environment and is, therefore, not applicable for protecting ship hulls or maritime infrastructure against fouling. It could work in industrial cooling water systems, but this option was not further investigated. In general, the current methods to prevent fouling in cooling water systems seem to fulfil the needs of the industry.

The chemical anti-fouling strategies of seaweeds are based on the production of a broad range of metabolites with the potential to reduce settlement and/or development of fouling organisms.

Although the effectiveness of several of these metabolites has been shown on experimental scale, none of these substances has made it into a commercial product so far. An important reason is the expensive and long lasting registration process that is required for bringing a new biocide to the market, sometimes in combination with the relatively high production costs of the compounds. The commercial application of bio-based compounds for anti-fouling purposes is, therefore, not attractive.

Apart from producing anti-fouling metabolites themselves, seaweeds can also support specific microbes that have little or no negative impact on their condition, but that prevent the settlement of more harmful species. A similar strategy, where a fouling species with low negative impact is favoured and supported, can have potential to manage fouling in an environmental friendly way on man-made surfaces where some drag is acceptable. This would be a new way to deal with biofouling, as alternative for fighting the constant battle against all fouling organisms which is common practice until now.

As spin-off of the exploring study presented in this report, a proposal for a joint industry project will be prepared that aims to investigate the potency of favouring low negative impact fouling organisms to manage biofouling on offshore infrastructures. 


\section{Quality Assurance}

Wageningen Marine Research utilises an ISO 9001:2015 certified quality management system. This certificate is valid until 15 December 2021. The organisation has been certified since 27 February 2001. The certification was issued by DNV GL. 


\section{References}

Abarzua, S. \& Jakubowski, S. (1995). Biotechnological investigation for the prevention of biofouling .1. Biological and biochemical principles for the prevention of biofouling. Mar. Ecol.-Prog. Ser. 123, 301-312.

Aldred, N., Scardino, A., Cavaco, A., de Nys, R. \& Clare, A. (2010). Attachment strength is a key factor in the selection of surfaces by barnacle cyprids (Balanus amphitrite) during settlement. Biofouling, 26(3), 287-299. https://doi.org/10.1080/08927010903511626

Almeida, J.R. \& Vasconcelos, V. (2015). Natural anti-fouling compounds: Effectiveness in preventing invertebrate settlement and adhesion. Biotechnology Advances 33, 343-357.

Alzieu, C., Sanjuan, J., Deltreil, J.P. \& Borel, M. (1986). Tin contamination in Arcachon Bay - effects on oyster shell anomalies. Mar. Pollut. Bull. 17, 494-498.

Amara, I., Miled, W., Ben Slama, R. \& Ladhari, N. (2018). Anti-fouling processes and toxicity effects of anti-fouling paints on marine environment. A review. Environ. Toxicol. Pharmacol. 57, 115-130.

Amsler, C.D. \& Fairhead, V.A. (2005). Defensive and sensory chemical ecology of brown algae, Advances in Botanical Research. Academic Press, pp. 1-91.

Antizar-Ladislao, B. (2008). Environmental levels, toxicity and human exposure to tributyltin (TBT)contaminated marine environment. A review. Environ. Int. 34, 292-308.

Armstrong, E., Boyd, K.G. \& Burgess, J.G. (2000). Prevention of marine biofouling using natural compounds from marine organisms, Biotechnology Annual Review. Elsevier, pp. 221-241.

Armstrong, E., Yan, L., Boyd, K.G., Wright, P.C. \& Burgess, J.G. (2001). The symbiotic role of marine microbes on living surfaces. Hydrobiologia 461, 37-40.

Bhadury, P. \& Wright, P.C. (2004). Exploitation of marine algae: biogenic compounds for potential anti-fouling applications. Planta 219, 561-578.

Bonar, D.B., Weiner, R.M. \& Colwell, R.R. (1986). Microbial-invertebrate interactions and potential for biotechnology. Microbial Ecology 12, 101-110.

Bryan, P. J., Qian, P. Y., Kreider, J. L. \& Chia, F. S. (1997). Induction of larval settlement and metamorphosis by pharmacological and conspecific associated compounds in the serpulid polychaete Hydroides elegans. Marine Ecology Progress Series, 146(1-3), 81-90. https://doi.org/10.3354/meps146081

Brock, E., Nylund, G., \& Pavia, H. (2007). Chemical inhibition of barnacle larval settlement by the brown alga Fucus vesiculosus. Mar. Ecol.-Prog. Ser. 337, 165-174.

Callow, M. E., Jennings, A. R., Brennan, A. B., Seegert, C. E., Gibson, A., Wilson, L. \& Callow, J. A. (2002). Microtopographic cues for settlement of zoospores of the green fouling alga Enteromorpha. Biofouling, 18(3), 229-236. https://doi.org/10.1080/08927010290014908

Campbell, A.H., Marzinelli, E.M., Gelber, J. \& Steinberg, P.D. (2015). Spatial variability of microbial assemblages associated with a dominant habitat-forming seaweed. Frontiers in Microbiology 6, 10.

Chambers, L.D., Hellio, C., Stokes, K.R., Dennington, S.P., Goodes, L.R., Wood, R.J.K. \& Walsh, F.C. (2011). Investigation of Chondrus crispus as a potential source of new anti-fouling agents. International Biodeterioration \& Biodegradation 65, 939-946.

Chen, L.G., Xia, C.H. \& Qian, P.Y. (2017). Optimization of anti-fouling coatings incorporating butenolide, a potent anti-fouling agent via field and laboratory tests. Progress in Organic Coatings 109, 22-29.

CORDIS BRPR960159. Environmentally compatible anti-fouling coatings for the protection of ships, water systems, fish cages and other immersed structures against aquatic growth.FP4BRITE/EURAM 3; @eEuropean Commission, 2001. URL: https://cordis.europa.eu/project/rcn/31953_en.html

Dahms, H. U. \& Dobretsov, S. (2017). Anti-fouling compounds from marine macroalgae. Marine Drugs, 15(9). https://doi.org/10.3390/md15090265

Davis, A.R., Targett, N.M., McConnell, O.J. \& Young, C.M. (1989). Epibiosis of marine algae and benthic invertebrates: Natural products chemistry and other mechanisms inhibiting settlement and overgrowth. Springer Berlin Heidelberg, Berlin, Heidelberg, pp. 85-114.

de Nys, R., Dworjanyn, S.A. \& Steinberg, P.D. (1998). A new method for determining surface concentrations of marine natural products on seaweeds. Mar. Ecol.-Prog. Ser. 162, 79-87.

Defoirdt, T., Boon, N., Bossier, P. \& Verstraete, W. (2004). Disruption of bacterial quorum sensing: an unexplored strategy to fight infections in aquaculture. Aquaculture 240, 69-88. 
Denys, R., Steinberg, P.D., Willemsen, P., Dworjanyn, S.A., Gabelish, C.L. \& King, R.J. (1995). Broadspectrum effects of secondary metabolites from the red alga Delisea pulchra in anti-fouling assays. Biofouling 8, 259-271.

Dobretsov, S.V. (1999). Effects of seaweeds and biofilm on settlement of blue mussel (Mytilus edulis L.) larvae. Biofouling 14, 153-165.

Dobretsov S. \& Wahl M. (2007). Larval recruitment of the blue mussel Mytilus edulis: The effect of flow and algae. Journal of Experimental Marine Biology and Ecology. 355(2), 137-144.

https://doi.org/10.1016/j.jembe.2007.12.018

Dobretsov, S., Dahms, H.U., Harder, T. \& Qian, P.Y. (2006). Allelochemical defense against epibiosis in the macroalga Caulerpa racemosa var. turbinata. Mar. Ecol.-Prog. Ser. 318, 165-175.

Dobretsov, S., Teplitski, M. \& Paul, V. (2009). Mini-review: Quorum sensing in the marine environment and its relationship to biofouling. Biofouling 25, 413-427.

Dobretsov, S., Teplitski, M., Bayer, M., Gunasekera, S., Proksch, P. \& Paul, V.J. (2011). Inhibition of marine biofouling by bacterial quorum sensing inhibitors. Biofouling 27, 893-905.

Dworjanyn, S.A., de Nys, R. \& Steinberg, P.D. (1999). Localisation and surface quantification of secondary metabolites in the red alga Delisea pulchra. Marine Biology 133, 727-736.

Dworjanyn, S.A., de Nys, R. \& Steinberg, P.D. (2006). Chemically mediated anti-fouling in the red alga Delisea pulchra. Mar. Ecol.-Prog. Ser. 318, 153-163.

Egan, S., Holmström, C. \& Kjelleberg, S. (2001a). Pseudoalteromonas ulvae sp. nov., a bacterium with anti-fouling activities isolated from the surface of a marine alga. International Journal of Systematic and Evolutionary Microbiology 51, 1499-1504.

Egan, S., James, S., Holmstrom, C. \& Kjelleberg, S. (2001b). Inhibition of algal spore germination by the marine bacterium Pseudoalteromonas tunicata. FEMS Microbiol. Ecol. 35, 67-73.

El Ayari, T., Bierne, N. \& El Menif, N.T. (2018). Imposex incidence in Stramonita haemastoma (Gastropoda: Muricidae) from the Mediterranean and Atlantic coast after tributyltin global ban. J. Sea Res. 134, 10-15.

Engel, S., Puglisi, M.P., Jensen, P.R. \& Fenical, W. (2006). Antimicrobial activities of extracts from tropical Atlantic marine plants against marine pathogens and saprophytes. Marine Biology 149, 991-1002.

Forêt, M., Barbier, P., Tremblay, R., Meziane, T., Neumeier, U., Duvieilbourg, E. \& Olivier, F. (2018). Trophic cues promote secondary migrations of bivalve recruits in a highly dynamic temperate intertidal system. Ecosphere, 9(12), 1-20. https://doi.org/10.1002/ecs2.2510

Fusetani, N. \& Clare, A.S. (eds) (2006). Anti-fouling compounds. Springer e-books, Berlin, New York ISBN: 9783540300168

Gittens, J.E., Smith, T.J., Suleiman, R. \& Akid, R. (2013). Current and emerging environmentallyfriendly systems for fouling control in the marine environment. Biotechnology Advances 31, 17381753.

Goecke, F., Labes, A., Wiese, J. \& Imhoff, J.F. (2010). Chemical interactions between marine seaweeds and bacteria. Mar. Ecol.-Prog. Ser. 409, 267-299.

Halat, L., Galway, M.E., Gitto, S. \& Garbary, D.J. (2015). Epidermal shedding in Ascophyllum nodosum (Phaeophyceae): seasonality, productivity and relationship to harvesting. Phycologia 54, 599-608.

Hellio, C., Bremer, G., Pons, A.M., Le Gal, Y. \& Bourgougnon, N. (2000). Inhibition of the development of microorganisms (bacteria and fungi) by extracts of marine algae from Brittany, France. Applied Microbiology and Biotechnology 54, 543-549.

Hellio, C., De La Broise, D., Dufossé, L., Le Gal, Y. \& Bourgougnon, N. (2001a). Inhibition of marine bacteria by extracts of seaweeds: potential use for environmentally friendly anti-fouling paints. Marine Environmental Research 52, 231-247.

Hellio, C., Thomas-Guyon, H., Culioli, G., Piovettt, L., Bourgougnon, N. \& Le Gal, Y. (2001b). Marine antifoulants from bifurcaria bifurcata (phaeophyceae, cystoseiraceae) and other brown seaweeds. Biofouling 17, 189-201.

Hellio, C., Berge, J.P., Beaupoil, C., Le Gal, Y. \& Bourgougnon, N. (2002). Screening of marine algal extracts for anti-settlement activities against microalgae and seaweeds. Biofouling 18, 205-215.

Hentzer, M., Riedel, K., Rasmussen, T.B., Heydorn, A., Andersen, J.B., Parsek, M.R., Rice, S.A., Eberl, L., Molin, S., Hoiby, N., Kjelleberg, S. \& Givskov, M. (2002). Inhibition of quorum sensing in Pseudomonas aeruginosa biofilm bacteria by a halogenated furanone compound. Microbiology-(UK) $148,87-102$.

ICES. 2019. ICES VIEWPOINT: Biofouling on vessels - what is the risk, and what might be done about it? In Report of the ICES Advisory Committee, 2019, vp.2019.01. https://doi.org/10.17895/ices.advice.4679

Khfaji, A.K. \& Boney, A.D. (1979). Antibiotic effects of crustose germlings of the red alga Chondrus crispus Stackh on benthic diatoms. Ann. Bot. 43, 231-232. 
Kobak, J. (2001). Light, gravity and conspecifics as cues to site selection and attachment behaviour of juvenile and adult Dreissena polymorpha Pallas , 1771. Journal of Molluscan Studies, 67, 183-189.

Kobayashi, N. \& Okamura, H. (2002). Effects of new anti-fouling compounds on the development of sea urchin. Mar. Pollut. Bull. 44, 748-751.

Kotsiri, M., Protopapa, M., Mouratidis, S., Zachariadis, M., Vassilakos, D., Kleidas, I., Samiotaki M. \& Dedos, S. G. (2018). Should I stay or should I go? The settlement-inducing protein complex guides barnacle settlement decisions. The Journal of Experimental Biology, 221, 13 pp. https://doi.org/10.1242/jeb.185348

Kupper, F.C., Kloareg, B., Guern, J. \& Potin, P. (2001). Oligoguluronates elicit an oxidative burst in the brown algal kelp Laminaria digitata. Plant physiology 125, 278-291.

Lam, C., Harder, T. \& Qian, P. Y. (2003). Induction of larval settlement in the polychaete Hydroides elegans by surface-associated settlement cues of marine benthic diatoms. Marine Ecology Progress Series, 263, 83-92. https://doi.org/10.3354/meps263083

Larsson, A. I., Granhag, L. M. \& Jonsson, P. R. (2016). Instantaneous flow structures and opportunities for larval settlement: Barnacle larvae swim to settle. PloS One, 11(7), 1-17. https://doi.org/10.1371/journal.pone.0158957

Leal, I., Bouchard, É., Flores, A. A. V. \& Tremblay, R. (2018). Trophic cues as possible triggers of mussel larval settlement in southeastern Brazil. Aquatic Living Resources, 31(26), 26. https://doi.org/10.1051/alr/2018013

Little B.J. \& J.S. Lee (2007). Microbiologically influenced corrosion. John Wiley \& Sons, Inc., Hoboken, New Jersey USA

Manefield, M., Rasmussen, T.B., Henzter, M., Andersen, J.B., Steinberg, P., Kjelleberg, S. \& Givskov, M. (2002). Halogenated furanones inhibit quorum sensing through accelerated LuxR turnover. Microbiology-(UK) 148, 1119-1127.

Mann, K.H. (1973). Seaweeds - their productivity and strategy for growth. Science 182, 975-981.

Manzo, S., Buono, S. \& Cremisini, C. (2008). Predictability of copper, irgarol, and diuron combined effects on sea urchin Paracentrotus lividus. Archives of Environmental Contamination and Toxicology 54, 57-68.

Maraldo, K. \& Dahllöf, I. (2004). Indirect estimation of degradation time for zinc pyrithione and copper pyrithione in seawater. Mar. Pollut. Bull. 48, 894-901.

Marechal, J.P., Culioli, G., Hellio, C., Thomas-Guyon, H., Callow, M.E., Clare, A.S. \& Ortalo-Magne, A. (2004). Seasonal variation in anti-fouling activity of crude extracts of the brown alga Bifurcaria bifurcata (Cystoseiraceae) against cyprids of Balanus amphitrite and the marine bacteria Cobetia marina and Pseudoalteromonas haloplanktis. J. Exp. Mar. Biol. Ecol. 313, 47-62.

Mokrini, R., Mesaoud, M.B., Daoudi, M., Hellio, C., Maréchal, J.-P., El Hattab, M., Ortalo-Magné, A., Piovetti, L. \& Culioli, G. (2008). Meroditerpenoids and derivatives from the brown alga Cystoseira baccata and their anti-fouling properties. Journal of Natural Products 71, 1806-1811.

Nir, S. \& Reches, M. (2016). Bio-inspired anti-fouling approaches: the quest towards non-toxic and non-biocidal materials. Current Opinion in Biotechnology 39, 48-55.

Nylund, G.M. \& Pavia, H. (2005). Chemical versus mechanical inhibition of fouling in the red alga Dilsea carnosa. Mar. Ecol.-Prog. Ser. 299, 111-121.

Nylund, G.M., Cervin, G., Hermansson, M. \& Pavia, H. (2005). Chemical inhibition of bacterial colonization by the red alga Bonnemaisonia hamifera. Mar. Ecol.-Prog. Ser. 302, 27-36.

Okamura, H., Watanabe, T., Aoyama, I. \& Hasobe, M. (2002). Toxicity evaluation of new anti-fouling compounds using suspension-cultured fish cells. Chemosphere 46, 945-951.

Omae, I. (2003). Organotin anti-fouling paints and their alternatives. Appl. Organomet. Chem. 17, 81105.

Othmani, A., Bunet, R., Bonnefont, J.L., Briand, J.F. \& Culioli, G. (2016). Settlement inhibition of marine biofilm bacteria and barnacle larvae by compounds isolated from the Mediterranean brown alga Taonia atomaria. J. Appl. Phycol. 28, 1975-1986.

Puglisi, M.P., Engel, S., Jensen, P.R. \& Fenical, W. (2007). Antimicrobial activities of extracts from Indo-Pacific marine plants against marine pathogens and saprophytes. Marine Biology 150, 531540.

Qian, P. Y., Rittschof, D., Sreedhar, B. \& Chia, F. S. (1999). Macrofouling in unidirectional flow: Miniature pipes as experimental models for studying the effects of hydrodynamics on invertebrate larval settlement. Marine Ecology Progress Series, 191, 141-151. https://doi.org/10.3354/meps191141

Qian, P.Y., Xu, Y. \& Fusetani, N. (2010). Natural products as anti-fouling compounds: recent progress and future perspectives. Biofouling 26, 223-234.

Ren, D., Sims, J.J. \& Wood, T.K. (2002). Inhibition of biofilm formation and swarming of Bacillus subtilis by (5Z)-4-bromo-5-(bromomethylene)-3-butyl-2(5H)-furanone. Lett. Appl. Microbiol. 34, 293-299. 
Rickert, E., Wahl, M., Link, H., Richter, H. \& Pohnert, G. (2016). Seasonal variations in surface metabolite composition of Fucus vesiculosus and Fucus serratus from the Baltic Sea. PLoS One 11, 18.

Rolin, C., Inkster, R., Laing, J. \& McEvoy, L. (2017). Regrowth and biofouling in two species of cultivated kelp in the Shetland Islands, UK. J. Appl. Phycol. 29, 2351-2361.

Saha, M. \& Wahl, M. (2013). Seasonal variation in the anti-fouling defence of the temperate brown alga Fucus vesiculosus. Biofouling 29, 661-668.

Salama, A.J., Satheesh, S. \& Balqadi, A.A. (2018). Anti-fouling activities of methanolic extracts of three macroalgal species from the Red Sea. J. Appl. Phycol. 30, 1943-1953.

Satheesh, S., Ba-akdah, M.A. \& Al-Sofyani, A.A. (2016). Natural anti-fouling compound production by microbes associated with marine macroorganisms - A review. Electronic Journal of Biotechnology 21, 26-35.

Scardino, A., de Nys, R., Ison, O. \& Connor, W. O. (2003). Microtopography and anti-fouling properties of the shell surface of the bivalve molluscs Mytilus galloprovincialis and Pinctada imbricata. Biofouling, 19(S1), 221-230. https://doi.org/10.1080/0892701021000057882

Schultz, M.P., Bendick, J.A., Holm, E.R. \& Hertel, W.M. (2011). Economic impact of biofouling on a naval surface ship. Biofouling 27, 87-98.

Scott L. Morello, Philip O. Yund 2016: Response of competent blue mussel (Mytilus edulis) larvae to positive and negative settlement cues. Journal of Experimental Marine Biology and Ecology. Volume 480, July 2016, Pages 8-16. https://doi.org/10.1016/j.jembe.2016.03.019

Seilacher, A. (2005). Whale barnacles: Exaptational access to a forbidden paradise. Paleobiology 31 , 27-35.

Wahl, M. (1989). Marine epibiosis .1. Fouling and anti-fouling - some basic aspects. Mar. Ecol.-Prog. Ser. 58, 175-189.

Wahl, M., Goecke, F., Labes, A., Dobretsov, S. \& Weinberger, F. (2012). The second skin: Ecological role of epibiotic biofilms on marine organisms. Frontiers in Microbiology. https://doi.org/10.3389/fmicb.2012.00292.

Walters, L.J., Hadfield, M.G. \& Smith, C.M. (1996). Waterborne chemical compounds in tropical seaweeds: positive and negative cues for larval settlement. Marine Biology 126, 383-393.

Wikström, S.A. \& Pavia, H. (2004). Chemical settlement inhibition versus post-settlement mortality as an explanation for differential fouling of two congeneric seaweeds. Oecologia 138, 223-230.

Yebra, D.M., Kiil, S. \& Dam-Johansen, K. (2004). Anti-fouling technology-past, present and future steps towards efficient and environmentally friendly anti-fouling coatings. Progress in Organic Coatings 50, 75-104.

Zhao, Y., Liu, Y.Y., Sun, J., Sha, H.T., Yang, Y., Ye, Q., Yang, Q., Huang, B.Q., Yu, Y.D. \& Huang, H. (2018). Acute toxic responses of embryo-larval zebrafish to zinc pyrithione (ZPT) reveal embryological and developmental toxicity. Chemosphere 205, 62-70. 


\section{Justification}

Report 048/19

Project Number: 4315100094

The scientific quality of this report has been peer reviewed by the a colleague scientist and the head of the department of Wageningen Marine Research.

Approved: $\quad$ Dr. Klaas Kaag

Researcher

signature. Maas Maag

Date:

16th of May 2019

Approved: $\quad$ Dr. Ir. T.P. Bult

Director

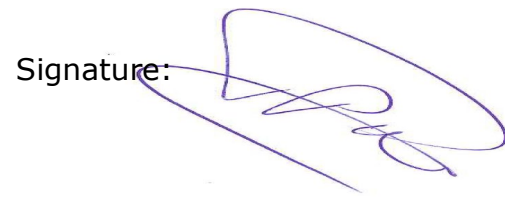

Date:

16th of May 2019 
Wageningen Marine Research

$\mathrm{T}+31(0) 317480900$

E: marine-research@wur.nl

www.wur.eu/marine-research

Visitors' address

- Ankerpark 271781 AG Den Helder

- Korringaweg 7, 4401 NT Yerseke

- Haringkade 1, 1976 CP IJmuiden
With knowledge, independent scientific research and advice, Wageningen Marine Research substantially contributes to more sustainable and more careful management, use and protection of natural riches in marine, coastal and freshwater areas.

Wageningen Marine Research is part of Wageningen University \& Research. Wageningen University \& Research is the collaboration between Wageningen University and the Wageningen Research Foundation and its mission is: 'To explore the potential for improving the quality of life' 